\title{
ANALISIS NIAI TAMBAH KERIPIK KENTANG DAGING (KRITING) VARIAN PEDAS
}

\author{
ANALYSIS OF VALUE ADDED AGROINDUSTRY MEAT POTATO SCHIPS (KRITING) \\ VARIANT SPICY
}

\section{Nurhana Jafaruddin}

Fakultas Pertanian Universitas Ma'soem

Jl. Raya Cipacing, Jatinangor, Kabupaten Sumedang, Jawa Barat 45363

*E-mail: Jafaruddinnurhana@gmail.com

(Diterima 26-04-2021; Disetujui 03-06-2021)

\begin{abstract}
ABSTRAK
Tujuan penelitian ini adalah untuk mengetahui proses pengolahan keripik kentang daging pedas (kriting) dan nilai tambah yang diperoleh pada pengolahan keripik kentang daging pedas. Pengambilan lokasi penelitian dilakukan secara sengaja (purposive), menggunakan metode studi kasus. Penelitian ini menggunakan analisis metode Hayami. Hasil yang diperoleh adalah proses pengolahan keripik kentang daging (kriting) menggunakan teknik semi modern yang meliputi pengupasan kentang, penyerutan kentang, pencucian dan penirisan kentang, penggorengan kentang, pembuatan daging sebagai campuran keripik kentang, pembuatan bumbu keripik kentang daging, pencampuran keripik kentang dan daging dengan bumbu. Nilai tambah yang diperoleh dari pengolahan kentang menjadi keripik kentang daging (kriting) sebesar Rp. 70.000,45 per kilogram. Rasio nilai tambah yang diperoleh sebesar 44,16 persen dengan faktor konversi sebesar 0,518 dan koefisien tenaga kerja sebesar $0,35 \mathrm{JKO}$. Tingkat keuntungan yang diperoleh pengusaha sebesar 84,48 persen. Nilai output sebesar Rp. 135.136,00 per kilogram.
\end{abstract}

Kata Kunci : Nilai Tambah, Agroindsutri, Kentang, Keripik Kentang Daging Pedas.

\section{ABSTRACT}

The purpose of this research is to know the process of meat potato chips processing (kriting) variant spicy and the value added was obtained on the processing of meat potato chips variant spicy. The research location was chosen purposively, using the case study method. This study uses the Hayami method analysis. The results obtained are the processing of meat potato chips (kriting) using semi-modern techniques that include potato stripping, potato shrinkage, leaching and potato drying, potato frying, the addition of meat as a mixture of potato chips, the production of potato chips with meat flavor, mixing potato chips and meat with seasoning. The value added was obtained from the process of potatoes into meat potato chips (kriting) variant spycy is Rp. 70,000.45 per kilogram. Value-added ratio is 44.16 percent with conversion factor of 0.518 and labor coefficient of $0.35 \mathrm{JKO}$. The rate of profit earned by employers is 84.48 percent. Output value is Rp. 135,136,00per kilogram.

Keywords : Value Added, Agroindustry, Potato, Meat Potato Chips Spicy

\section{PENDAHULUAN}

Sistem agribisnis terdiri atas subsistem input (agroindustri hulu), usaha tani (pertanian), sistem output (agroindustri hilir), pemasaran dan penunjang. Kegiatan agroindustri tidak dapat dilepaskan dari sistem agribisnis secara keseluruhan karena agroindustri 
dapat menghasilkan nilai tambah hasil pertanian (Masyhuri, 1994).

Ciri produk pertanian menurut Soekartawi (2002) bersifat produk musiman, mudah rusak, mudah busuk (bulky), mudah diserang hama dan penyakit, tidak mudah didistribusikan ke lain tempat, bersifat lokal dan kondisional, mempunyai kegunaan yang beragam, kadang memerlukan keahlian khusus yang ahlinya sulit disediakan, sebagai bahan baku produk lain disamping juga dikonsumsi langsung, sebagai "produk sosial".

Pengembangan industri berbasis pertanian (agroindustri) cukup strategis untuk dijadikan salah satu upaya memperpanjang sifat dari produk pertanian. Agroindustri sebagai salah satu subsistem penting dalam sistem agribisnis memiliki potensi untuk mendorong pertumbuhan ekonomi yang tinggi (Purnomo, 2011). Tujuan kegiatan agroindustri yang mengubah bentuk primer menjadi produk baru yang lebih tinggi nilai ekonomisnya setelah melalui proses pengolahan, maka akan dapat memberikan nilai tambah karena dikeluarkannya biaya - biaya sehingga terbentuk harga yang lebih tinggi dan keuntungannya lebih besar bila dibandingkan tanpa melalui proses pengolahan.

Agroindustri memberikan manfaat ganda (multiplier effect) terhadap pembangunan perekonomian nasional karena kemampuannya, yaitu: Meningkatkan nilai tambah (value added) produk pertanian primer, (2) Memperluas jangkauan daerah pemasaran, Memperluas kesempatan kerja dan membuka peluang usaha baru, (4) Meningkatkan pendapatan petani sebagai pemasok hasil pertanian primer, (5) Penganekaragaman produk pangan dan hasil pertanian olahan baik secara vertikal maupun horizontal, dan Meningkatkan daya saing ekonomi Indonesia melalui produksi pangan dan hasil pertanian olahan yang memiliki standar mutu internasional (Rasmikayati dkk., 2020).

Menurut Hayami dkk (1987), pengertian nilai tambah adalah pertambahan nilai suatu produk atau komoditas karena mengalami proses pengolahan, pengangkutan, ataupun penyimpanan dalam suatu produksi. Proses pengolahan nilai tambah dapat didefinisikan sebagai selisih antara nilai produk dengan nilai bahan baku dan input lainnya, tidak termasuk tenaga kerja. Nilai tambah merupakan nilai yang ditambahkan pada suatu produk karena 
masuknya unsur pengolahan menjadi lebih baik, dengan menggunakan tenaga kerja dan teknologi yang sederhana.

Kentang sebagai salah satu bahan pangan yang mempunyai kadar air yang cukup tinggi. Menurut Perdani dkk (2019), bahwa kentang varietas Granola mengandung kadar air sekitar 83.48\% sehingga mudah rusak. Kentang varietas Granola selain dapat dikonsumsi dalam keadaan segar, juga cocok untuk dimanfaatkan menjadi berbagai hasil industri makanan olahan salah satunya yaitu keripik kentang.

Industri keripik kentang di Indonesia menunjukkan perkembangan yang cukup tajam. Hal ini ditunjukkan dengan peningkatan permintaan kebutuhan bahan baku kentang untuk industri keripik (Asgar, 2013). Jenis kentang yang digunakan pada umumnya untuk membuat keripik kentang, yaitu kentang Dieng. Kentang Dieng cocok untuk dijadikan keripik kentang karena mempunyai rasa sedikit manis dengan tekstur yang renyah, warna kuning rata, rasa yang enak dan renyah, serta gurih dari keripik kentang.

Pengolahan keripik kentang daging ini merupakan kegiatan off farm. Kegiatan off farm bertujuan untuk memberikan nilai tambah pada kentang, daging sebagai campuran pada keripik kentang dan cabai sebagai penambah rasa pedas pada keripik kentang daging sehingga dapat dikonsumsi dengan jangka waktu yang panjang.

Pengolahan keripik kentang daging (Kritng) varian pedas salah satu contoh dari kegiatan agroindustri. Pengolahan agroindustri dapat memberikan laba dan keuntungan yang besar dapat diperoleh dengan melakukan penekanan pada biaya usahatani melalui proses pengolahannya (Wahyudi dan Wulandari, 2019). Agroindustri keripik kentang daging (Kriting) varian pedas bertujuan untuk membuka lapangan pekerjaan dan meningkatkan cita rasa dari kentang dan daging yang sudah diolah agar memperoleh nilai jual yang tinggi di pasaran.

\section{METODE PENELITIAN}

Penelitian dilakukan pada agroindustri keripik kentang daging (Kriting) Si Uni sebagai agroindustri kentang di Kelurahan Jakasetia, Kecamatan Bekasi Selatan, Kota Bekasi. Penelitian dilaksanakan pada bulan Februari 2021.

Pemilihan lokasi penelitian ditentukan secara sengaja (purposive) dengan pertimbangan bahwa agroindustri 
tersebut sudah cukup lama berpengalaman dalam menjalankan usahanya. Metode penelitian yang digunakan adalah metode studi kasus dengan menggunakan alat bantu kuesioner sebagai alat pengumpulan data serta dilakukan wawancara langsung secara mendalam kepada key informan yaitu pelaku usaha agroindustri keripik kentang daging (Kriting) pedas.

Analisis data yang digunakan pada penelitian ini adalah analisis kualitatif dan kuantitatif. Analisis kualitatif dipakai untuk menjelaskan bagaimana cara mengolah kentang menjadi produk akhir yang siap dikonsumsi yaitu keripik kentang daging (Kriting) varian pedas. Analisis kuantitatif digunakan untuk mengetahui besarnya nilai tambah yang dilakukan pada agroindusti keripik kentang daging (Kriting) pada penelitian ini.

Data yang telah terkumpul dari hasil wawancara dan pengisian kuesioner serta pengamatan langsung di lokasi penelitian, selanjutnya data tersebut diolah menggunakan metode Hayami. Metode Hayami ini adalah metode yang sering dan umum digunakan pada subsistem pengolahan dalam agribisnis. Analisis nilai tambah menggunakan metode Hayami bertujuan untuk mengetahui produktivitas nilai output, nilai tambah dan keuntungan.

\section{HASIL DAN PEMBAHASAN}

\section{Proses Pengolahan Kentang Menjadi Keripik Kentang Daging (Kriting) Varian Pedas}

Proses pengolahan keripik kentang daging (Kriting) pedas sama seperti pembuatan keripik kentang lain pada umumnya, yaitu meliputi tahap pengupasan, penyerutan, perendaman, pencucian, penirisan, penggorengan, penambahan bumbu, dan pengemasan.

Perbedaan yang terjadi pada pengolahan keripik kentang daging (Kriting) dengan pengolahan keripik kentang lainnya terdapat pada proses pencampuran daging sebagai toping pada keripik kentang. Proses pembuatan keripik kentang daging memerlukan waktu 28 jam dalam satu kali produksi.

Kegiatan mengolah kentang menjadi keripik kentang dan tambahan daging dengan varian pedas tersebut dapat memperpanjang jangka waktu yang cukup lama untuk dapat dikonsumsi yaitu empat bulan. Langkah-langkah pengolahan keripik kentang daging (Kriting) varian pedas dijelaskan pada Gambar 1. 


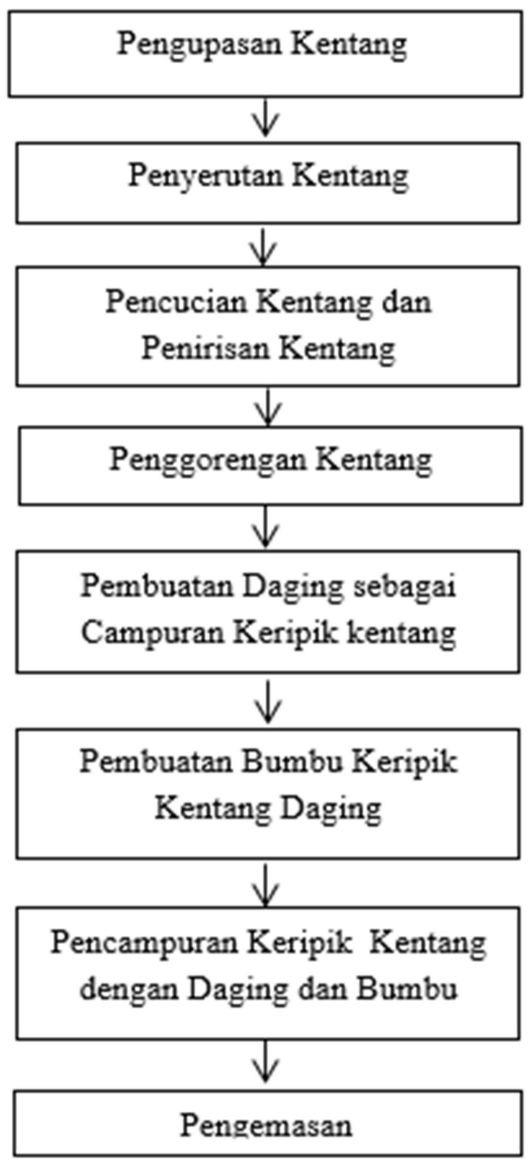

Gambar 1. Diagram alir proses pembuatan keripik kentag daging (Kriting)

Proses pengolahan keripik kentang daging melalui bebeapa tahapan, yaitu:

a. Tahap pertama, yaitu pengupasan kentang agar terpisah antara kulit kentang dan daging kentang. Proses pengupasan kentang ini menggunakan pisau pengupas kentang.

b. Tahap kedua, yaitu penyerutan kentang bertujuan untuk mengubah kentang berukuran utuh menjadi berukuran lebih kecil sehingga lebih mudah untuk dikonsumsi dan dikemas. Proses penyerutan kentang menggunakan alat penyerut kentang.

c. Tahap ketiga, yaitu pencucian kentang tujuannya supaya kentang bersih dari kotoran- kotoran yang menempel, setelah itu ditiriskan menggunakan saringan.

d. Tahap keempat, yaitu penggorengan kentang, bertujuan untuk merubah kentang menjadi keripik kentang. Penggorengan adalah salah satu cara pengurangan kadar air dari kentang sehingga daya simpan menjadi lebih panjang (Estiasih dan Ahmadi, 2009).

e. Tahap kelima, yaitu pembuatan daging sebagai campuran keripik kentang. Pembuatan daging sebagai campuran keripik kentang melalui tahap perebusan daging, kemudian dilakukan pendinginan dengan cara disimpan dengan suhu yang normal, setelah itu baru daging akan dimasukkan ke dalam lemari pendingin agar daging mudah didiiris dengan hasil yang baik. Setelah itu dilakukan pemotongan daging, dan penggorengan daging hingga matang.

f. Tahap keenam, yaitu pembuatan bumbu dimulai dari pengupasan bawang merah, pemotongan cabai merah dan cabai rawit, pengirisan bawang merah mengunakan mesin 
atau blender sehingga meminimalisir waktu dalam pembuatan bumbu. Setelah bumbu telah disiapkan maka akan dilakukan tahap penggorengan bumbu yang sudah disiapkan hingga matang, garam dan lada bubuk dimasukkan, kemudian diaduk hingga merata dan dimasak hingga matang.

g. Tahap ketujuh, adalah pencampuran keripik dengan daging dan bumbu. Proses pencampuran keripik dengan campuran keripik yaitu daging dan bumbu akan dicampur menjadi satu diaduk hinga merata.

h. Tahap terakhir, yaitu proses pengemasan dilakukan agar keripik kentang daging dapat menjaga produk agar tetap bersih, lebih mudah dikonsumsi oleh konsumen dan juga menambah daya tarik. Produk dapat disimpan dalam jangka waktu lama jika pengemasan yang digunakan tepat (Estiasih dan Ahmadi, 2009). Proses pengemasan ini mencangkup pengemasan dengan memasukkan keripik kentang daging ke dalam toples, kemudian disegel dengan label nama produk sehingga dapat dikenal dengan masyarakat, dan menjadi salah satu ciri khas dari produk tersebut.

\section{Nilai Tambah Agroindustri Keripik Kentang Daging (Kriting) Varian Pedas}

Nilai tambah adalah pertambahan nilai suatu komoditas karena mengalami proses pengolahan, pengangkutan ataupun penyimpanan dalam suatu produksi. Proses pengolahan nilai tambah dapat didefinisikan sebagai selisih antara nilai produk dengan nilai biaya bahan baku dan input lainnya, tidak termasuk tenaga kerja. Sedangkan marjin adalah selisih antara nilai produk dengan harga bahan bakunya saja. Marjin ini tercakup komponen faktor produksi yang digunakan, yaitu tenaga kerja, dan input lainnya (Hayami dkk, 1987).

Menurut Aminah (2013), konsep nilai tambah adalah suatu pengembangan nilai yang terjadi karena adanya proses mengubah bentuk (form utility), menyimpan (time utility), adanya perlakuan dan jasa yang menyebabkan bertambahnya kegunaan, dan nilai komoditas pertanian. Proses pengolahan kentang menjadi keripik kentang daging menyebabkan adanya nilai tambah pada kentang tersebut.

Harga jual pada produk hasil olahan kentang yang berupa keripik kentang daging akan menjadi lebih tinggi jika dibandingkan dengan kentang yang belum mengalami pengolahan. Besarnya 
nilai tambah keripik kentang daging dan distribusi marjin dari pemanfaatan faktorfaktor produksi dalam pengolahan dapat diketahui dengan melakukan analisis nilai tambah.

Komponen utama perhitungan nilai tambah adalah bahan baku, output atau produk, input tenaga kerja dan sumbangan input lainnya. Dasar penghitungan nilai tambah pengolahan kentang menjadi keripik kentang daging menggunakan per satuan kilogram artinya satu $\mathrm{kg}$ keripik kentang daging selama satu kali proses produksi.

Bahan baku utama yang digunakan adalah kentang dieng atau kentang kuning dengan varietas granola. Untuk memperoleh hasil yang baik dan mendapatkan nilai yang tinggi, maka diperlukan bahan baku penolong atau sumbangan input lain. Bahan yang digunakan adalah daging sapi, bawang merah, garam, cabai merah, cabai rawit, minyak goreng, gas, listrik. Selain itu, untuk kemasan diperlukan toples dan label.

Sumbangan input lain yang digunakan selama satu kali proses produksi. Jumlah harga yang digunakan sumbangan input lain dalam proses satu kali produksi untuk mengolah $80 \mathrm{~kg}$ bahan baku kentang yaitu sebesar
Rp2.006.756,00. Sumbangan input lain per kg bahan baku yang digunakan dalam satu kali produksi sebesar Rp25.084,45.

Sumbangan input lain dalam memproduksi keripik kentang daging dalam satu kali produksi dibutuhkan daging sapi sebanyak $\quad 8 \quad \mathrm{~kg}$ untuk dijadikan campuran keripik kentang.

Bahan-bahan yang digunakan untuk pembuatan bumbu yang digunakan dalam proses produksi keripik kentang daging membutuhkan bawang merah sebanyak 4 $\mathrm{kg}$, garam 4 sendok atau $0,18 \mathrm{~kg}$, cabai merah $1 / 2 \mathrm{~kg}$ dan cabai rawit $1 / 4 \mathrm{~kg}$. Selanjutnya pada proses penggorengan dalam pembuatan keripik kentang daging juga membutuhkan minyak goreng sebanyak 8 bungkus dengan ukuran 2 liter atau 16 liter minyak goreng. Kemudian membutuhkan gas sebanyak 4 tabung dengan ukuran $3 \mathrm{~kg}$ atau sama dengan $12 \mathrm{~kg}$ gas.

Pembuatan keripik kentang daging membutuhkan listrik untuk pemakaian lemari pendingin sebagai penyimpan daging dan bawang merah. Listrik juga digunakan untuk pemakaian pompa air dalam mencuci kentang, merebus daging, dan mencuci peralatan masak, dan pemaikan blender untuk pembuatan bumbu. 
Agroindustri keripik kentang daging pedas menggunakan alat produksi semi-modern seperti menggunakan pisau pengupas kentang, penyerut kentang, menggunakan alat penirisan, menggunakan lemari pendingin, penggunaan blender. Menurut Sutarman dkk (2015) dari hasil penelitiannya mengatakan bahwa suatu produksi menggunakan alat modern yang lebih canggih supaya hasil produksinya maksimal dan cepat.

Tabel I. Analisis Nilai Tambah Keripik Kentang Daging (Kriting) Varian Pedas

\begin{tabular}{lr}
\hline Variabel & \multicolumn{1}{c}{ Nilai } \\
\hline I. Output, Input dan Harga & \\
1. Output $(\mathrm{kg})$ & 41,44 \\
2. Input $(\mathrm{kg})$ & 80,00 \\
3. Tenaga Kerja (JKO) & 28,00 \\
4. Faktor Konversi & 0,518 \\
5. Koefisien Tenaga Kerja & \\
(JKO/kg) & 0,35 \\
6. Harga Output $(\mathrm{Rp} / \mathrm{kg})$ & $135.136,00$ \\
7. Upah Tenaga Kerja (Rp/JKO) & $9.286,00$ \\
\hline II. Penerimaan dan Keuntungan & \\
\hline 8. Harga bahan baku (Rp/kg) & $14.000,00$ \\
9. Sumbangan input lain (Rp/kg) & $25.084,45$ \\
10. Nilai Output $(\mathrm{Rp} / \mathrm{kg})$ & $70.000,45$ \\
11. a. Nilai Tambah (Rp/kg) & $30.916,00$ \\
$\quad$ b. Rasio Nilai Tambah $(\%)$ & 44,16 \\
12. a. Pendapatan Tenaga Kerja & \\
(Rp/kg) & $3.250,10$ \\
$\quad$ b. Pangsa Tenaga Kerja (\%) & 10,51 \\
13. a. Keuntungan (Rp/kg) & $27.665,90$ \\
Tingkat Keuntungan $(\%)$ & 84,48 \\
\hline Sumber Data Prim 2021 (diolah)
\end{tabular}

Sumber: Data Primer 2021 (diolah)

Hasil yang didapatkan setelah mengalami proses pengolahan kentang menjadi keripik kentang daging pedas, maka didapatkan output sebesar 41,44 $\mathrm{kg}$; dan apabila dikemas ke dalam toples akan menghasilkan 112 toples keripik kentang daging yang berukuran 300 gram dan diberi label nama produk tersebut yaitu keripik kentang daging (kriting).

Bahan baku (input) yaitu kentang, dalam satu kali periode produksi dibutuhkan kentang sebanyak $80 \mathrm{~kg}$. Harga kentang per kg yaitu Rp14.000,00 jadi untuk kentang sebanyak $80 \mathrm{~kg}$ harga yang harus dibayar yaitu Rp1.120.000,00. Setelah kentang melalui proses pengolahan, hasil output diperoleh sebanyak 41,44 kg keripik kentang daging pedas. Maka dapat dilihat faktor konversi yang dihitung berdasarkan pembagian antara nilai output berupa keripik kentang daging sebanyak 41,44 $\mathrm{kg}$ dengan input yang digunakan berupa kentang sebanyak $80 \mathrm{~kg}$ dengan hasil 0,518. Harga output (keripik kentang daging) Rp135.136,00 per kg.

Tenaga kerja yang dihitung adalah semua tenaga kerja yang berperan langsung dalam proses produksi keripik kentang daging. Waktu yang digunakan untuk produksi keripik kentang daging yaitu 2 hari dengan 2 orang tenga kerja dan masing-masing melakukan pekerjaan selama 7 jam per hari. Jadi, jumlah jam orang kerja (JKO) yang digunakan sebesar 28 (JKO) per satu kali produksi.

Berdasarkan nilai JKO tersebut, maka diperoleh koefisien tenaga kerja 
sebesar 0,35 JKO per Kg. Artinya untuk mengolah $1 \mathrm{~kg}$ bahan baku dibutuhkan tenaga kerja 0,35 jam kerja orang. Untuk upah tenaga kerja selama proses produksi adalah sebesar Rp9.286,00 per JKO. Nilai tersebut diperoleh dari hasil bagi total upah tenaga kerja dengan jumlah jam kerja orang untuk satu kali proses produksi.

Harga bahan baku kentang adalah sebesar Rp.14.000,00 per Kg. Sumbangan input lain yang merupakan jumlah dari biaya bahan baku penolong adalah sebesar Rp25.084,45 per $\mathrm{kg}$. Untuk harga output per kg yang dijual berupa toples sebanyak 112 unit dengan harga Rp50.000,00 dengan cara harga output per toples dibagi berat output per toples dikali 1.000 gr maka didapatkan hasil Rp135.136,00 per kg. Sedangkan nilai output (keripik kentang daging) diperoleh sebesar Rp70.000,45 per kg. Nilai tersebut merupakan hasil perkalian antara faktor konversi dengan harga output (keripik kentang daging).

Nilai tambah yang dihasilkan dari pengolahan keripik kentang daging adalah Rp30.916,00 untuk satu kg bahan baku kentang menjadi keripik kentang daging. Nilai tambah tersebut merupakan selisih antara nilai output dengan biaya bahan baku dan sumbangan input lain.
Rasio nilai tambah yang diperoleh dalam usaha ini adalah 44,16 persen menunjukan persentase nilai tambah terhadap nilai output.

Reyne (1987) dalam Hubeis (1997) mengemukakan bahwa rasio nilai tambah rendah apabila memiliki persentase kurang dari 15 persen, rasio nilai tambah sedang apabila memiliki persentase 15 persen sampai 40 persen dan rasio nilai tambah tinggi apabila memiliki persentase lebih dari 40 persen. Hal ini menunjukan bahwa perusahaan ini memiliki rasio nilai tambah tinggi, karena berada di atas 40 persen.

Pendapatan tenaga kerja dari setiap satu kilogram bahan baku utama menjadi keripik kentang daging sebesar Rp3.250,10. Pendapatan tenaga kerja diperoleh dari hasil perkalian antara nilai koefisien tenaga kerja dengan upah tenaga kerja. Pangsa tenaga kerja merupakan persentase pendapatan tenaga kerja terhadap nilai tambah, yaitu 10,51 persen dalam proses produksi satu kilogram keripik kentang daging.

Besarnya keuntungan yang diperoleh produsen dari setiap satu kilogram bahan baku utama adalah Rp27.665,90. Tingkat keuntungan yang diperoleh produsen ini sangat besar yaitu mencapai 84,48 persen. 
Tingkat keuntungan yang diperoleh produsen cukup tinggi sebesar 84,48 persen pada kegiatan agroindustri keripik kentang daging (Kriting). Menurut Hardiyanto (2020) dari hasil penelitiannya, peluang pengembangan agroindustri cukup menjanjikan karena agroindustri tersebut mampu menghasilkan laba sebesar 29,18 persen dari modal yang dikeluarkan dalam satu kali proses produksi. Penelitian pada agroindustri keripik kentang daging (Kriting) memperoleh tingkat keuntungan sebesar 84,48 persen yang artinya lebih besar dari 29,18 dan cukup menjajikan.

\section{KESIMPULAN DAN SARAN}

Proses produksi keripik kentang daging menggunakan teknik semi modern yang meliputi pengupasan kentang, penyerutan kentang, pencucian dan penirisan kentang, pembuatan daging sebagai campuran keripik kentang, pembuatan bumbu keripik kentang daging, pencampuran keripik kentang dan daging dengan bumbu serta pengemasan dan pemeberian label nama produk. Pembuatan keripik kentang daging ini dipengaruhi oleh ukuran kentang, sumbangan input lain, dan proses pembuatannya.

Besarnya nilai tambah yang diperoleh perusahaan yaitu 27.665,90 untuk satu $\mathrm{kg}$ bahan baku kentang menjadi keripik kentang daging. Artinya peluang pengembangan agroindustri cukup menjanjikan karena agroindustri mampu menghasilkan laba yang cukup besar mencapai 84,48 persen.

Agroindustri keripik kentang daging (Kriting) sebaiknya lebih menginovasi varian rasa produk sehingga dapat menarik lebih banyak konsumen dan meningkatkan nilai tambah yang lebih besar. Produsen usaha keripik kentang daging perlu menjaga ketersediaan bahan baku, meningkatkan produksi, serta memperhatikan biaya pembelian bahan baku dan input lainnya tanpa mengurangi kualitasnya untuk menjaga keberlanjutan agroindustri.

\section{DAFTAR PUSTAKA}

Asgar, A. (2013). Umbi Kentang (Solanum Tuberosum L.) Klon 395195.7 Dan Cip 394613.32 Yang Ditanam Di Dataran Medium Mempunyai Harapan Untuk Keripik. Iptek Hortikultura. Balai Penelitian Tanaman Sayuran.

Estiasih, T. \& Ahmadi, K. (2009). Teknologi Pengolahan Pangan. PT. Bumi Aksara. Jakarta.

Hardiyanto, T. (2020). Profitabilitas dan Peluang Pengembangan Agroindustri Gula Kelapa dalam Sistem Agribisnis Kelapa (Cocos nucifera L.): Suatu Kasus Di Desa Sukanagara Kecamatan Lakbok Kabupaten Ciamis. Jurnal Agritekh 
(Jurnal Agribisnis dan Teknologi Pangan), Vol 1 No. 1.

Hayami, Y., Kawagoe, T., Morooka, Y \& Siregar, M. (1987). Agricultural Marketing and Processing in Upland Java. A Perspective from a Sunda Village. The CPGRT Centre. Bogor.

Masyhuri. (1994). Pengembangan Agribisnis dalam Era Globalisasi. Fakultas Pertanian UGM. Yogyakarta.

Nur, Aminah M.L. (2013). Analisis Nilai Tambah dalam Pengolahan Susu Kedelai pada Skala Industri Rumah Tangga Di Kota Medan. Program Studi Agribisnis. Fakultas Pertanian. Universitas Sumatera Utara. Medan.

Perdani, C. G., Amaludin, F.J \&Wijana, S. (2019). Formulasi Kerupuk Kentang Granola (Solanum tuberosum L.) Sebagai Makanan Kuliner Khas Tengger Jawa Timur. Jurnal Pangan dan Agroindustri, Vol 7 No. 3.
Purnomo, D. (2011). Karakteristik, Penerapan, dan Pengembangan Agroindustri Hasil Pertanian di Indonesia. Universitas Padjadjaran. Bandung.

Rasmikayati, E., \& Saefudin, B. R. (2018). Analisis Faktor-Faktor Yang Mampu Mendorong Petani Mangga Untuk Meningkatkan Perilaku Agribisnisnya Pada Era Globalisasi. Paradigma Agribisnis, Vol 1 No 1.

Soekartawi. (2002). Prinsip Dasar Ekonomi Pertanian. Teori dan Aplikasi. PT Raja Grafindo Persada. Jakarta.

Sutarman, S., Rochdiani, D., \& Hardiyanto, T. (2015). Analisis Usaha Agroindustri Baglog Jamur Tiram di Desa Margaluyu Kecamatan Cikoneng Kabupaten Ciamis. Jurnal Ilmiah Mahasiswa Agroinfo Galuh, Vol 2 No. 1.

Wahyudi, A \& Wuladari, S. (2019). Inovasi Teknologi Dan Kelembagaan Untuk Mendukung Usahatani Lada Di Kalimantan Timur. Jurnal Littri, Vol 25, No. 2. 